\title{
15 Yaşın Altındaki Çocuklar Arasında Cinsel İlişki: Olgu Sunumu
}

\section{Sexual Activity among Children under the Age of 15: A Case Report}

\section{Kenan Karbeyaz ${ }^{1}$, Ceysu Dinç ${ }^{2}$, Yasemin Günay Balci ${ }^{3}$}

${ }^{1}$ Adli Tip Şube Müdürlüğ̈̈, Eskişehir

${ }^{2}$ Eskisehir Barosu, Eskisehir

${ }^{3}$ Sitkı Koçman Üniversitesi Tip Fakültesi Adli Tip AD. Muğla

\section{Özet}

Ülkemizde çocukların cinsel sağlık ve cinsel davranışlarla ile ilgili bilgileri yetersizdir. Sunulan olguda 15 yaşından küçük iki çocuğun, birbirleri ile cinsel etkileșimleri hakkındaki ve adli sürecin tartışılması amaçlanmıştır. Çocuklara cinsel davranışlar ile ilgili eğitim verilmesi önemlidir. Çocukluk çağı için, konunun uzmanlarından görüş alınarak, cinsel davranışlar ile ilgili ayrıntılı yasal düzenleme yapılması gerektiği düşünülmektedir.

Anahtar Kelimler: Çocuklar arası, Cinsellik, Çocuk, Adli Tıp.

\section{Giriş}

Cinsel dokunulmazlığa karşı suçlar, cinsel tacizden, cinsel davranışlarla bir kimsenin vücut dokunulmazlığını ihlale ve en uç noktada da vücuda organ veya sair bir cisim sokulmasını da içine alan, onay verecek durumda olmayanlara yönelen ya da onay ve eşitliğin olmadığ durumlarda zorlama, tehdit, hile ya da kandırma sonucu oluşan her türlü eylemi kapsar $(1,2)$. Gençlerde cinsel etkileşim ile ilgili yapılan araştırmalarda; 12 13 yaşlarında bedensel değişimlerin fark edildiği, öz bakımın arttığı, karşı cins ile daha az vakit geçirilmeye başlandığ 1 belirlenmiştir. 14-15 yaşlarında ise; karşı cins ile cinsel temasa

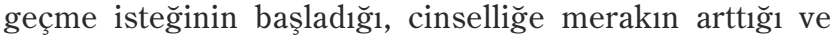
öpüşme, okşama gibi cinsel eylemlere istek duyulduğu belirtilmiştir (3-8).

Türk Ceza Kanunu'nun 103. maddesi, on beş yașını tamamlamamış veya tamamlamış olmakla birlikte fiilin hukuki anlam ve sonuçlarını algılama yeteneği gelişmemiş olan çocuklara karşı gerçekleștirilen her türlü cinsel davranıșı suç olarak kabul etmiş ve şikâyete tabi olmadığını belirtmiştir (9). Kanun maddesine göre, bu yaş grubu için şüphelinin kaç yaşında olduğunun veya cinsiyetinin önemi yoktur. Bunun tek istisnasını Türk Ceza Kanunu'nda 6545 sayılı Kanunun 59. maddesiyle yapılan değişiklik oluşturmaktır. Söz konusu değişiklik uyarınca çocukların cinsel istismarı suçunun

Sorumlu Yazar: Doç. Dr. Kenan Karbeyaz

Adli Tip Şube Müdürlüğü Eskişehir

E-mail: drkenankarbeyaz@hotmail.com

\section{Abstract}

Children's information about legislations related to sexual health and sexual behaviours are inadequate in our country. The aim in this case report was to discuss the legal process about sexual interaction between two children under 15 years old. It is important to provide children with an adequate education about sexual behaviour. It is believed that a detailed legal regulation by also taking experts opinions is needed for the childhood.

Keywords: Among Children, Sexuality, Child, Forensic Medicine.

'yalnızca sarkıntılık düzeyinde kalmış boyutuyla sınırlı olmak üzere' failinin çocuk olması hâlinde soruşturma ve kovușturma yapılması mağdurun, velisinin veya vasisinin şikâyetine bağlıdır (10).

Sunulan olguda 15 yașından küçük iki çocuğun, birbirleri ile cinsel etkileşimlerinin, yargıya taşınması ile yaşanan adli sürecin tartışılması amaçlanmıştır.

\section{Olgu Sunumu}

Adli tahkikat dosyasından; 14 yaşında bir kız çocuğu ile komşusu olan 14 yaşında bir erkek çocuğun her ikisinin de, gündüz vakti kız çocuğun ailesi ile birlikte yaşadığı evde, kızın annesi tarafından yarı çıplak vaziyette bulunduğu ve kızın ailesi tarafindan polise başvurulduğu öğrenildi.

Cumhuriyet Savc1lığı, Adli Tıp Şube Müdürlüğünden; 14 yaşındaki kız çocuğu ile ilgili olarak, vücut dokunulmazlığının cinsel yönden ihlal edilip edilmediği, direncinin kırılmasını sağlayacak ölçünün ötesinde cebir ve şiddet izinin bulunup bulunmadığı ve cinsel saldırıya maruz kalıp kalmadığı ile ilgili olarak rapor istemiștir.

14 yaşındaki kız ile yapılan görüşmede, 8. sınıfa gittiŏini, evin tek çocuğu olduğunu, derslerinin iyi olduğunu, herhangi bir rahatsızlığının olmadığını, ilaç kullanmadığını, sigara veya başka bir madde bağımlılığının olmadığını, kendisinin kimseden şikayetçi olmadığını, erkek arkadaşını kendisinin eve çă̆ırdığını, birbirlerini öptüklerini, sarıldıklarını ve birbirlerine dokunduklarını ama başka bir şey yapmadıklarını, erkek arkadaşının kaç yaşında olduğunu bilmediğini, cinsel 
ilişkinin nasıl olduğunu internetten gördüğünü, ama kimseyle böyle bir şey yaşamadığını, okulda cinsellikle ilgili bilgi verilmediğini, daha önce hiç adliyeye veya karakola gitmediğini ifade etmiştir.

Kızın annesi ile yapılan görüşmede, kızını komşularının oğlu ile birlikte yakaladığını, bu sırada kızın üzerinin çıplak olduğunu, altında eşofman olduğunu, kızının bakire olup olmadığını öğrenmek istediğini, kızının daha önce başından böyle olaylar geçmediğini, olaydan beri ailecek perişan olduklarını, küçük bir mahallede yaşadıklarını ve olayın duyulmasını istemediklerini ifade etmiştir.

$\mathrm{K}_{1 z}$ çocuğu, muayene ile ilgili bilgi verildiğinde, çekinmesine karşın muayene yapılmasına izin vermiştir. Yapılan fizik muayenesinde vücudunda herhangi bir travmatik lezyona rastlanılmadı. Genital muayenede himen intakt olup, şahsın halen bakire olduğu, anal muayenede anal mukoza ve tonusunun doğal olduğu saptandı. Şahsın cinsel dokunulmazlığının ihlal edildiğine yönelik maddi delile rastlanılmadığ psikiyatrisinden görüş alınması gerektiği rapora yazıldı. Çocuk Psikiyatrisi uzmanı değerlendirmesinde, herhangi bir ruhsal patoloji saptanmadığı öğrenilmiştir.

Aynı gün aynı Cumhuriyet Savcısı imzası ile 14 yaşındaki erkek çocuk ile ilgili şube müdürlüğümüzden, Türk Ceza Kanunu 31/2. maddesi kapsamında, işlediği iddia olunan cinsel saldırı suçu ile ilgili olarak, fiilin hukuki sonuçlarını algılama ve davranışlarını yönlendirme yeteneğinin gelişip gelişmediğine ilişkin rapor talep edilmiştir.

14 yaşındaki erkek ile yapılan görüşmede; 8 sınıfa gittiğini, 3 kardeşin en büyüğü olduğunu, daha önce hiç karakola veya mahkemeye gitmediğini, ailesi ile birlikte yaşadı̆̆ını, olay günü kız arkadaşı ile birlikte onların evine gittiklerini, kötü bir şey yapmadıklarını, birbirlerini öptüklerini, cinsel ilişkiye nasıl girildiğini internetten gördüğünü, kendisinin hiç böyle bir şey yapmadığını, o sırada kız arkadaşının annesinin eve geldiğini ve kendilerini yanlış anladığını, pişman olduğunu ve korktuğunu ifade etmiştir.

Şahsın yapılan muayenesinde ruhsal bir patoloji saptanmamıştır. Ancak cinsel saldırı suçu ile ilgili olarak fiilin hukuki anlam ve sonuçlarını algılama ve davranışlarını yönlendirme yeteneğinin gelişmediği kanaatine varılmıştır.

Cumhuriyet Savcılığı, erkek çocuğun fiilin hukuki anlam ve sonuçlarını algılama ve davranışlarını yönlendirme yeteneğinin gelişmediğini dikkate alarak olayla ilgili takipsizlik kararı vermiştir.

\section{Tartışma ve Sonuç}

Ülkemizde yapılan araştırmalar çocukların cinsel sağlık hakkında bilgilerinin yeterli olmadığını göstermiştir $(11,12)$.
Ayrıca çocukların cinsellikle ilgili yasal düzenlemeler hakkında da bilgilerinin olmadığı görülmektedir (13).

Ülkemizde Türk Ceza Kanunu'nun (TCK) 103. maddesinde, on beş yaşını tamamlamamış veya tamamlamış olmakla birlikte fiilin hukuki anlam ve sonuçlarını algılama yeteneği gelişmemiş olan çocuklara karşı gerçekleştirilen her türlü cinsel davranışı suç olarak kabul etmiş ve şikâyete tabi tutulmamıştır .(9). 6545 sayılı Kanunla suça sürüklenen çocuk yönünden getirilmiş olan şikayet şartı ise suçun yalnızca belli ağırlıktaki haliyle sınırlı kalmıştır. Kaldı ki şikayet suçun varlığını etkileyen bir kurucu unsur değil yalnızca suçtan haberdar olan adli makamların soruşturma ve sonrasında kovuşturma yapabilmesi için gerekli olan bir ceza muhakemesi koşuludur (10). TCK'nın 31. maddesi gereği 12-15 yaş arası çocuklarda, işlediği iddia olunan fiilin hukukî anlam ve sonuçlarını algılama ve bu fiille ilgili olarak davranışlarını yönlendirme yeteneğinin gelişip gelişmediği açısından muayeneleri gerekmektedir. Buna göre ceza sorumluluğunun olmadığına veya ceza indirimi gerektiğine hükmedilir (9). Bu kanun maddelerinde cinsiyet ile ilgili bir hüküm bulunmamaktadir.

Suça sürüklenmiş çocuklar ile ilgili yapılan çalışmalarda, 15 yaşının altındaki çocukların cinsel saldırı suçu işlediği iddia edilmiş ve istatistiklere yansımıştır (13-16). Bilginer ve arkadaşlarının yaptığı bir çalışmada, cinsel suç açısından, çocukların mağdur veya sanık olma durumları irdelenmiştir. $\mathrm{Bu}$ çalışmada mağdurların \% 78,8'inin kız çocuğu olduğu sanıkların ise tamamının erkek olduğu saptanmıştır (17). Literatürdeki olguların adli tahkikatları ayrıntılı olarak bilinmemektedir. Ancak 15 yaşının altında erkek çocuklarının, cinsel saldırı suçu açısından şüpheli olduğunu bildiren çalışmalar olmasına karşın, literatürde kız çocuğunun cinsel saldırı suçu açısından şüpheli olarak değerlendirildiği bir çalışmaya rastlanılmamıştır. Sunulan olguda 14 yaşındaki iki çocuğun birbirlerine cinsel eylemlerinin olduğu anlaşılmaktadır. Ancak tahkikattan anlaşıldı̆̆ çocukta eylemden sorumludur. Buna rağmen kız çocuğu mağdur, erkek çocuk ise şüpheli olarak belirtilmiştir. Oysa ki erkek çocukta 15 yaşından küçüktür ve isteği dahilinde de olsa, yaşı küçük olduğundan, vücut dokunulmazlığı cinsel yönden ihlal edilmiştir. Bu olguda kız çocuğunun mağdur, erkek çocuğunun ise şüpheli olarak değerlendirilmesinin, toplumsal algı ve cinsiyet temelli yaklaşımla ilgili olduğ u düşünülmektedir.

Sunulan olguda 14 yaşında, henüz cinselliği yaşamamış bir çocuğun, karakola gitmesinin, ifade vermesinin ve genital muayene yapılmasının, ağır bir travma yaratacağ kuşkusuzdur.

Vücut dokunulmazlığının cinsel yönden ihlali ile ilgili yasal 
düzenlemelerde, 15 yaşının altındaki tüm bireylere karşı işlenen her türlü cinsel eylem, şikayet durumuna bakılmaksızın suç olarak tanımlanmıştır (9). Kanun maddesi çocuklar için ayrı bir düzenleme getirmiştir. Yasalarımızda çocuklar arasında flört, cinsel oyun, akranlar arası cinsel aktivite ilişkisi tanımlayan madde yoktur. Tamamı cinsel saldırı içinde değerlendirilmektedir.

Sonuç olarak çocuklarda cinsel davranışların yaratacağı, yasal ve psikososyal problemlerinin önlenmesi amaciyla; çocukluk çağında sağlıklı cinsel bilgi kaynaklarına ulaşılmasının sağlanmasına dair eğitsel politikalar geliştirilmesi, önyargılar ile mücadele edilmesi, okullarda cinsel eğitim ve ergenlik danışmanlı̆̆ ${ }_{1}$ verilmesi gerekmektedir. Çocukluk çağı için, konunun uzmanlarından görüş alınarak, cinsel davranışlar ile ilgili ayrıntılı yasal düzenleme yapılması gerektiği düşünülmektedir.

\section{Kaynaklar}

1. Polat O, İnanıcı MA, Aksoy ME. Adli Tıp Ders Kitabı. Nobel Tıp Kitapevleri İstanbul, 1997;340-60.

2. Shaw JA (editor). Sexually aggressive behavior. In: Sexual Aggression. First ed. Washington, DC: American Psychiatric Press, 1999, 3-40.

3. Coleman E. Sexual health education in medical school: a comprehensive curriculum. Virtual Mentor. 2014;16(11):903-8.

4. Shindel AW, Parish SJ. Sexuality education in North American medical schools: current status and future directions. J Sex Med 2013;10(1):3-18.
5. Coleman E, Elders J, Satcher D, Shindel A, Parish S, Kenagy G, Bayer CR, Knudson G, Kingsberg S, Clayton A, Lunn MR, Goldsmith E, Tsai P, Light A. Summit on medical school education in sexual health: report of an expert consultation. J Sex Med. 2013;10(4):924-38.

6. Ferrara E, Pugnaire MP, Jonassen JA, O’Dell K, Clay M, Hatem D, Carlin M. Sexual health innovations in undergraduate medical education. Int J Impot Res. 2003 Oct;15 Suppl 5:S46-50.

7. Dennis KJ, Elstein M. Education in sexuality in the medical curriculumClin Obstet Gynaecol. 1980;7(2):183-91.

8. Set T, Dağdeviren N, Aktürk Z, Ergenlerde cinsellik. Genel Tip Derg 2006;16(3):137-41.

9. Yalvaç G. (editör). Karșılaștırmalı-Gerekçeli TCK. CMK. CGTIKK ve İlgili Kanunlar ile Yönetmelikler. Adalet Yayınevi. Ankara 2014:218-224.

10. Toroslu N. Ceza Mukamesi Hukuku. Ceza Muhakeme Koşulları, Ş่̇kayet. Savaş Yayınevi. Ankara. 2014: 70-110.

11. Giray H, Kılıç B. Bachelor women and reproductive health. Sürekli Tip Eğitimi Dergisi 2004;13(8):286-90.

12. Devletkușu C, Ögel K, Erdoğan FN. Risk Altında İki Grubun Cinsel Bilgilerinin Karşılaştırılması: Sokakta Yaşayan ve Kanunla İhtilafa Düșen Ergenler. Turkiye Klinikleri J Foren Med 2010;7 (2):55-63.

13. Akcan R, Çekin N. Cinsel suçlu (!) olarak çocuk. Adli Tıp Dergisi 2011;25(1):49-70.

14. Kurtuluş A, Salman N, Günbet G, Boz B, Cenger CD, Acar K. Denizli ilinde 12-15 yaş arasındaki suça sürüklenen çocukların sosyodemografik özellikleri. Pamukkale Tip Dergisi 2009;2(1):814.

15. Aydın B, Turla A, Kocakaya M, Kararslan B. Samsun'da suç ișlediği iddiası ile Emniyet Müdürlüğü'ne gelen/getirilen çocuklar. Adli Psikiyatri Dergisi 2004: 1: 45-53.

16. Tamer H, Aciksari O, Keten A, Karanfil R, Avsar A. Sociodemographic data of delinquent children in Kahramanmaras.J For Med 2014;28(2):115-20

17. Bilginer Ç, Hesapçıŏlu ST, Kandil S. Çocukluk çağ istismarı: mağdur ve sanık açısından çok yönlü bakıș. Düsünen Adam The Journal of Psychiatry and Neurological Sciences 2013;26:55-64. 